\title{
The Belgica 121 expedition to the Western Antarctic Peninsula: a detailed biodiversity census
}

\author{
Bruno Danis $\ddagger$, Henrik Christiansen§, Charlène Guillaumoł ${ }^{\ddagger}$, Franz Maximilian Heindler ${ }^{\S}$, Quentin \\ Jossart ${ }^{\ddagger}$, , Camille Moreau ${ }^{\ddagger}$, Francesca Pasottifl, Henri Robert\#, Ben Wallis ${ }^{\natural}$, Thomas Saucède" \\ ‡ Université Libre de Bruxelles, Brussels, Belgium \\ $\S$ KULeuven, Leuven, Belgium \\ | Vrije Universiteit Brussel, Brussels, Belgium \\ II UGent, Gent, Belgium \\ \# EMC2, Brussels, Belgium \\ a Ocean Expeditions, Sydney, Australia \\ « UMR 6282 Biogéosciences, Univ Bourgogne Franche-Comté, CNRS, Dijon, France
}

Corresponding author: Bruno Danis (bdanis@ulb.ac.be)

Academic editor: Yasen Mutafchiev

Received: 23 Jun 2021 | Accepted: 15 Sep 2021 | Published: 23 Sep 2021

Citation: Danis B, Christiansen H, Guillaumot C, Heindler FM, Jossart Q, Moreau C, Pasotti F, Robert H, Wallis

B, Saucède T (2021) The Belgica 121 expedition to the Western Antarctic Peninsula: a detailed biodiversity census. Biodiversity Data Journal 9: e70590. https://doi.org/10.3897/BDJ.9.e70590

\begin{abstract}
Background

This dataset relates to the biodiversity census carried out during the Belgica 121 (B121) expedition to the Western Antarctic Peninsula from February to March 2019. One of the aims of the campaign was to explore the surroundings of the Gerlache Strait and to carry out a detailed biodiversity census focusing on inter- and subtidal shallow-water areas using both classic descriptive marine ecology methods, as well as state-of-the art techniques (habitat mapping, genetics, trophic ecology). The biodiversity census was carried out onboard a nimble research vessel, RV Australis. This dataset will offer access to the raw data on biodiversity occurrences, obtained using a range of methods described in this data paper.
\end{abstract}




\section{New information}

New raw biodiversity data for a poorly-sampled region (Western Antarctic Peninsula) with a special focus on shallow ecosystems.

\section{Keywords}

Southern Ocean, Belgica, low environmental impact, shallow waters, climate change, benthos

\section{Introduction}

Global warming-related environmental changes are expected for large areas of the Southern Ocean in terms of sea ice cover, ocean and glacier melting (Gutt et al. 2015). The Western Antarctic Peninsula (WAP) is one of Earth's regions where we observe the most rapid and dramatic environmental changes in marine ecosystems, with strong variations in the duration of the sea ice season, extended glacier retreats, ice shelf collapse, warming of surface waters and shifts in local primary production (Ducklow et al. 2013, Stammerjohn et al. 2008, Turner et al. 2014). These climate change related processes are significantly affecting marine ecosystems and their suitability to keyorganisms (Carlini et al. 2009, Clarke et al. 2007, Constable et al. 2014, Sahade et al. 2015, Pasotti et al. 2015). Furthermore, recent efforts in documenting the biodiversity of the Southern Ocean has shown that intensity in biological sampling has considerably varied between Antarctic regions and time periods since first expeditions were carried out (Griffiths et al. 2011, De Broyer et al. 2014). Most data in the distribution of sampling intensity, including animal tagging and watching, are from locations nearby national scientific bases and along main transit routes of research vessels that regularly visit these bases, mostly for logistic reasons (Griffiths 2010).

The WAP is a sea ice dependent ecosystem which is experiencing rapid, transitioninducing environmental changes (Ducklow et al. 2013, Turner et al. 2014). In a comprehensive synthesis paper, Gutt et al. (2015) showed that the spatial scale of past changes in sea ice extent is larger than that of ocean warming. The response of marine organisms and ecosystem processes to such environmental changes is still poorly understood (Siegert et al. 2019). Yet the available studies show, in general, a high sensitivity of these highly adapted species and hint to a vulnerability of the ecological processes that they mediate (Ducklow et al. 2013, Chown et al. 2015 and references therein). Insights on resilience, thresholds and tipping points for species, communities and ecosystems are, therefore, of paramount importance to the understanding of ongoing large-scale changes (Convey et al. 2014, Kennicutt et al. 2015, Oliver et al. 2015). Recent studies have shown that WAP fjord basins exhibited 3 to 38 -fold greater benthic megafaunal abundance than the open shelf and that local species diversity and trophic network complexity remained high from outer to inner fjord basins (Grange and Smith 2013), even if our current knowledge of faunal biodiversity is 
considered as patchy and incomplete (Friedlander et al. 2020). As WAP fjords also provide important habitat and foraging areas for Antarctic krill and Baleen whales, there is an urgent need to develop better understanding of the structure, dynamics and climatesensitivity of WAP subpolar fjord ecosystems (Grange and Smith 2013).

In February 2019, the Belgica 121 expedition (B121) aimed to fill knowledge gaps in this potential biodiversity hotspot (whilst limiting its environmental footprint) by making use of a

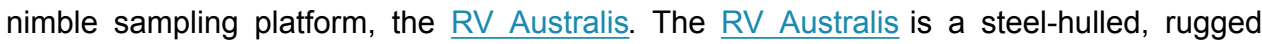
motor sailing vessel which carries a comprehensive range of safety, operational and navigational equipment. B121 sampled a broad area along the northern coast of the WAP, extending from the Berthelot Islands to the SW to Enterprise Islands to the NE and including a total of 15 stations selected for their contrasting conditions in terms of sea ice dynamics, glacier activity, biodiversity and oceanographic conditions and pressure by human visitors. This data paper relates to the biodiversity census carried out during the B121 expedition (for the full report, see Danis et al. 2019).

\section{Project description}

Title: The Belgica 121 expedition to the Western Antarctic Peninsula: a high resolution biodiversity census

\section{Personnel: Bruno Danis}

Study area description: The study area was primarily the Western Antarctic Peninsula in the Southern Ocean. B121 took place between February and March 2019, sampling 15 stations in 22 working days in an area extending from Berthelot $\left(65^{\circ} 19.751 \mathrm{~S}, 64^{\circ} 08.263\right.$ W) to Enterprise $\left(64^{\circ} 32.420 \mathrm{~S}, 61^{\circ} 59.899 \mathrm{~W}\right)$ Islands.

Design description: The overarching objective of the expedition was to gather samples and data to help build a benchmark to better understand the response of shallow benthic communities to variable glacial regimes in a fast-warming region of the Southern Ocean, the WAP. The collected samples are expected to help refine insights gained in the plasticity/resilience of these communities in the framework of the RECTO/vERSO projects (http://rectoversoprojects.be). The objective was tackled by using a multi-faceted approach, matched by the complementary competences of the scientific crew and sampling gear. The expedition was a unique opportunity to address a series of underlying scientific/logistic questions. Amongst these questions, the expedition focused on testing the concept of using a nimble platform for Antarctic marine biology fieldwork and its potential to fill knowledge gaps with a limited environmental impact, mapping the marine habitats in selected locations of the Gerlache Strait and assessing different biodiversity levels in various locations of the WAP, from the supratidal to $20 \mathrm{~m}$ depth.

Funding: The Belgian Science Policy Office (BELSPO): the bulk of the funding of the expedition was channelled through two research projects funded by BELSPO, RECTO (promoter: Isa Schön, Royal Belgian Institute of Natural Sciences) and vERSO (promoter: Bruno Danis, Université Libre de Bruxelles). The Cabinet Marcourt (Federation Wallonia- 
Brussels - Research, Education) supported the expedition for functioning and various equipment. The Belgian Federal Public Service Health, Food Chain Safety and Environment funded the ship time necessary to the visit of historic monument $N^{\circ} 45$ dedicated to the Belgica expedition, led by Adrien de Gerlache. The Fund for Scientific Research - FNRS and the Research Foundation - Flanders (FWO) have funded travel expenses. The B121 team also acknowledges financial support from the Fonds Léopold III and the Royal Belgian Zoological Society.

\section{Sampling methods}

Study extent: The expedition took place between 23 February and 24 March 2019. RV Australis departed from Ushuaia (Argentina) on February 23 and arrived at the first sampling station (Melchior Islands) on 27 February after crossing the Drake Passage. The last station was completed on 20 March and the expedition returned to Ushuaia on 24 March, a total of 22 days being devoted to the sampling effort, including bird and marine mammal observations. The sampling area focused on the WAP and extended from the Berthelot Islands to the SW to Enterprise Islands to the NE and included a total of 15 stations. Nearly half the stations were exhaustively sampled according to the initial protocol established (see Table 1, in bold), while others were partially worked out as timing, priorities, anchoring and weather allowed. Metchnikoff Point (MP) was visited in order to check the status of historic monument \#45 at the request of the Belgian Federal Service Food, Health and Environment Foundation.

Table 1.

Station list including location and sampling dates. Fully sampled stations are in bold.

\begin{tabular}{|c|c|c|c|c|c|}
\hline Stations & & Lat (S) & Long (W) & Arrival & Departure \\
\hline MI & Melchior Island & $64^{\circ} 19.246$ & $62^{\circ} 55.375$ & 27/02/2019 & $03 / 03 / 2019$ \\
\hline MP & Metchnikoff Point & $64^{\circ} 02.395$ & $62^{\circ} 34.078$ & 03/03/2019 & 03/03/2019 \\
\hline NH & Nekko Harbor & $64^{\circ} 50.565$ & $62^{\circ} 32.009$ & 03/03/2019 & $06 / 03 / 2019$ \\
\hline SM & SeaMount & $64^{\circ} 51.283$ & $62^{\circ} 36.136$ & 06/03/2019 & $06 / 03 / 2019$ \\
\hline UI & Useful Island & $64^{\circ} 43.146$ & $62^{\circ} 52.159$ & 06/03/2019 & $08 / 03 / 2019$ \\
\hline SK & Skontorp Cove & $64^{\circ} 54.190$ & $62^{\circ} 51.845$ & 08/03/2019 & $10 / 03 / 2019$ \\
\hline$A C$ & Alvaro Cove & $64^{\circ} 52.206$ & $63^{\circ} 00.054$ & 10/03/2019 & $11 / 03 / 2019$ \\
\hline HI & Hovgaard Islands & $65^{\circ} 06.057$ & $64^{\circ} 04.992$ & $11 / 03 / 2019$ & $13 / 03 / 2019$ \\
\hline $\mathrm{BI}$ & Berthelot Islands & $65^{\circ} 19.751$ & $64^{\circ} 08.263$ & $14 / 03 / 2019$ & $14 / 03 / 2019$ \\
\hline VS & Vernadsky Station & $65^{\circ} 14.746$ & $64^{\circ} 15.420$ & $14 / 03 / 2019$ & $15 / 03 / 2019$ \\
\hline CT & Cape Tuxen & $64^{\circ} 46.765$ & $63^{\circ} 40.381$ & $15 / 03 / 2019$ & $15 / 03 / 2019$ \\
\hline GR & Green Reef & $64^{\circ} 43.590$ & $63^{\circ} 16.974$ & $15 / 03 / 2019$ & $17 / 03 / 2019$ \\
\hline $\mathrm{AP}$ & Arctowski Peninsula & $64^{\circ} 35.362$ & $62^{\circ} 31.400$ & 18/03/2019 & $18 / 03 / 2019$ \\
\hline
\end{tabular}




\begin{tabular}{|l|l|l|l|l|l|}
\hline Stations & & Lat (S) & Long (W) & Arrival & Departure \\
\hline FH & Foyn Harbour & $\mathbf{6 4 ^ { \circ } 3 2 . 7 9 8}$ & $\mathbf{6 1 ^ { \circ } 5 9 . 8 8 5}$ & $\mathbf{1 8 / 0 3 / 2 0 1 9}$ & $\mathbf{2 0 / 0 3 / 2 0 1 9}$ \\
\hline EI & Enterprise Islands & $64^{\circ} 32.420$ & $61^{\circ} 59.899$ & $20 / 03 / 2019$ & $20 / 03 / 2019$ \\
\hline
\end{tabular}

Sampling description: The expedition aimed to focus on carrying out a detailed biodiversity census of shallow areas, from the intertidal to the subtidal zones (up to $20 \mathrm{~m}$ depth) at 15 stations within the Gerlache Strait. The stations were chosen for their contrasting conditions in terms of exposure to glaciers influence, iceberg scouring, to ocean water masses and currents (Drake Passage, Gerlache Strait etc.), geomorphology, penguins colonies and direct anthropogenic stressors (tourism and maritime traffic). Multiple types of gear were deployed (see Table 2), combining traditional marine ecology instruments (traps, nets, grabs, ...) and modern techniques (drones, ROVs). The team was mostly composed of young scientists who were acquainted with the use of several techniques. Each team had a specific project and was able to help others during sample processing stages. The initial stages of the expedition were exploratory (one full station would need up to 4 days to be completed) and were followed by more efficient sampling (1.5-2 days per station). Opportunistically, certain stations were partially sampled as a function of priorities and weather/anchoring conditions.

Table 2.

Types of gear deployed during the B121 expedition.

\begin{tabular}{|c|c|}
\hline Code & Full name \\
\hline AT & Amphipod trap \\
\hline $\mathrm{BN}$ & Bongo net \\
\hline CTD & CTD \\
\hline DIV & Scuba divers \\
\hline DR & Drone \\
\hline GN & Gillnet \\
\hline ITD & Intertidal sampling \\
\hline KELP & Kelp survey \\
\hline LF & Line fishing \\
\hline LL & Long line fishing \\
\hline NIS & Niskin bottle \\
\hline $\mathrm{RD}$ & Rauschert dredge \\
\hline ROV & Remotely operated vehicle \\
\hline SP & Snow petrel (hand collecting of feathers) \\
\hline TER & Terrestrial survey \\
\hline TOP & Top predator survey \\
\hline
\end{tabular}




\begin{tabular}{|l|l|}
\hline Code & Full name \\
\hline VV & Van Veen grab \\
\hline
\end{tabular}

Quality control: In the framework of the B121 expedition, data were aggregated and organised to ensure optimal use in the future for data publication in authoritative repositories and sample management. A series of data types were collected pertaining to navigation, weather conditions and sampling efforts (both biological and oceanographic). General procedures: Logbooks: hard copies of logbooks were completed on a daily basis by the B121 team. Data were organised in four different logbooks: sample, events, photo and diving. Logbooks were digitised and backed up on a daily basis. Spreadsheets: data from the logbooks were entered in a dedicated spreadsheet on a daily basis by two members of the B121 team: Charlène Guillaumot and Bruno Danis. Quality control (QC) was performed on the fly and feedback was given to the researchers on an ad hoc basis. Backup procedures: digital data and samples were backed up on a daily basis on two computers and two external hard drives. Sample (biodiversity) data: Sample data were gathered in MS Excel spreadsheets, specially prepared for the expedition. The structure of the spreadsheet is based upon the Darwin Core (DwC) standard, expanded for specific data and sample management needs. A template of this spreadsheet is provided in an annex for future use by other users. Identifications were carried out in the field and taxonomic data were cross-checked against the content of the World Register of Marine Species Taxon Match tool (http://www.marinespecies.org/aphia.php?p=match). For specimens we were not able to identify, help is sought from taxonomic experts and the dataset will be updated accordingly. Media data: Large amounts of video data were gathered in the framework of the expedition, both for outreach and research purposes. Underwater footage was taken by Bruno Danis and Henri Robert using a Remotely Operated Vehicle (ROV: OpenROV Trident). The footage was used essentially for exploration and dive site confirmation purposes. Aerial footage was shot by Franz Heindler, Camille Moreau and Bruno Danis using two DJI Mavic Pro drones, for documentation purposes. Macrophotography of the most common species was carried out by Quentin Jossart. Documentary footage was mostly shot by Franz Heindler and other members of the team. For more details, see the dedicated section below. Data publication: In the spirit of the Antarctic Treaty, Art. 3.1.c, the data emerging from the Belgica 121 sampling efforts will be made openly and freely available, in the best possible time limits and will follow the standards, policies and norms of behaviour as established by the Scientific Committee on Antarctic Research (SCAR). In particular, raw biodiversity data will be shared using dedicated, community-driven platforms, such as the biodiversity.aq initiative. Processed data will be made available through scientific publications and through the Belgica 121 website (www.belgica121.be).

Step description: Full description of methodologies is available from the B121 expedition report (Danis et al. 2019): http://belgica120.be/wp-content/uploads/2019/05/B121-Cruisereport.pdf. Briefly, for the macro and mega benthos survey, the diversity analysis was conducted using various sampling gears and investigation means as a necessary preliminary step to further ecological analyses, from individual species systematics to trophic and community analyses. Most common and key species (engineers or top 
predators) of the surveyed shallow water habitats (between 5 and $20 \mathrm{~m}$ depth) could be observed and identified during the dives, some of them sampled by hand picking or identified on video transects. This first inventory was widely complemented by samples collected with a Rauschert dredge, Van Veen grab and amphipod trap. For the soft sediment biodiversity, samples for meiofauna assemblage structure (taxa diversity, nematode diversity, biomass), were collected at each location by divers either by means of perspex push cores (3.6 cm diameter, quantitative) or by surface sediment scooping (qualitative). Where the sediment characteristics allowed core sampling, the sediment was sliced in different layer profiles $(0-1 \mathrm{~cm}, 1-2 \mathrm{~cm}, 2-5 \mathrm{~cm}, 5-10 \mathrm{~cm})$ for the whole core depth. At least three replicates were taken for the meiofauna characterisation at each location dive event. For the intertidal work, two sampling procedures were used to characterise the biodiversity and abundance on each site: (1) 10 quadrats (25 cm $\times 25 \mathrm{~cm}$ ) were randomly disposed at the low tide level. Presence and abundance of each species (morphotypes) were recorded within each quadrat and specimens were preserved in $96 \%$ ethanol for further identification and analyses; (2) to obtain a better overview of the total biodiversity, an exploration (1 hour) in the vicinity of the quadrats was also done to look for any species not found inside the quadrats. Fish biodiversity was addressed using three methods: (1) angling with hooks, line and sinker, (2) gill nets and (3) a cylindrical fish trap or fyke. Angling took place with standard commercial fishing rods, braided fishing line and rigs (Sabikis), equipped with multiple hooks of varying sizes and small, colourful lures, luminescent plastic beads and weights at the end in depths of 5-50 m. Hooks were sometimes baited with fish, mollusc or shrimp and used actively (jigging during daytime from the ship or zodiacs) or passively (fixed to the ship overnight). Two types of gill nets were used, measuring approximately $18 \mathrm{~m}$ in width and $1.5 \mathrm{~m}$ in height and with $4 \mathrm{~cm}$ and $8 \mathrm{~cm}$ mesh size (stretched), respectively. Nets were set in depths of 10-30 m and usually perpendicular to observed currents. The fish trap was deployed for at least $8 \mathrm{~h}$ in depths of 10-30 m, baited with fish, molluscs or shrimp. Finally, continuous monitoring of birds and marine mammals (species identification and headcount) was performed from the bridge or a spot offering the best visibility on deck. Bird/mammal standard counts are 30 min nonstop observation with binoculars for identification (if required) and age/sex determination when possible. A $300 \mathrm{~mm}$ telephoto lens was used for documentation and identification of species that pose identification issues in the field (e.g. Catharacta spp., Pachyptila spp.). GPS ship position and climatic conditions were recorded at each start and end position of counts. Counts were performed during daylight (from dawn to dusk) and only during good visibility (counts must be stopped when visibility is poor due to heavy fog or precipitation) to avoid bias in animal detection and subsequent false population estimates.

\section{Geographic coverage}

Description: The sampling area focused on the Western Antarctic Peninsula (WAP) and extended from Berthelot Island to the SW to Enterprise Island to the NE and included a total of 15 stations (see Fig. 1). Certain stations were exhaustively sampled, while others were partially worked out as timing, priorities, anchoring and weather allowed. Metchnikoff Point (MP) was visited in order to check the status of historic monument \#45. The birds 
and marine mammals survey was carried out all along the expedition and includes the whole expedition track, from Ushuaia (AR) to the WAP.

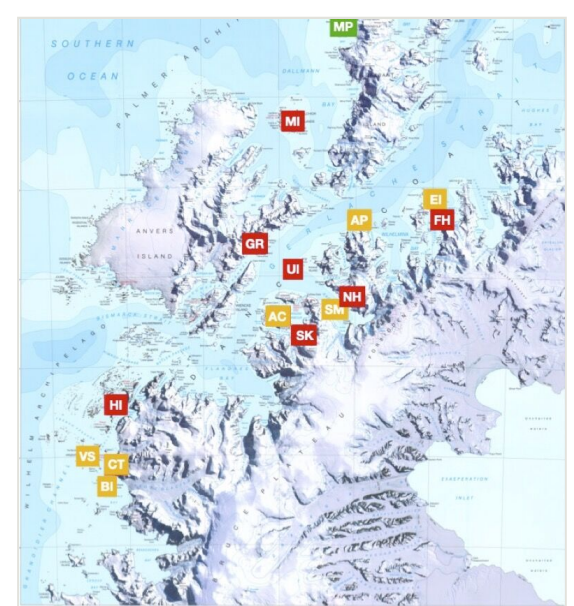

Figure 1. doi

General map of the sampling area. Red rectangles: complete stations; orange rectangles: partial stations; green rectangle: historic monument visit. Modified after MAP "Brabant Islands to Argentine Islands", British Antarctic Survey, Edition 1, 2008.

Coordinates: -66 and -54 Latitude; -68 and -62 Longitude.

\section{Taxonomic coverage}

Description: Specimens were collected in the intertidal and subtidal zones (max depth: 20 $\mathrm{m}$ ). Meiobenthos and megabenthos classes were analysed in particular. Identification of specimens is still ongoing, combining morphological analyses by expert taxonomists and a genetic approach where possible.

Taxa included:

\begin{tabular}{|l|l|}
\hline Rank & Scientific Name \\
\hline genus & Abyssorchomene \\
\hline genus & Acodontaster \\
\hline genus & Aequiyoldia \\
\hline species & Aequiyoldia eightsii \\
\hline order & Amphipoda \\
\hline order & Actinari \\
\hline species & Antarctomysis maxima \\
\hline
\end{tabular}




\begin{tabular}{|c|c|}
\hline species & Aphrodroma brevirostris \\
\hline species & Arctocephalus australis \\
\hline species & Arctocephalus gazella \\
\hline class & Asteroidea \\
\hline species & Balaenoptera bonaerensis \\
\hline family & Bathydraconidae \\
\hline class & Bivalvia \\
\hline phylum & Bryozoa \\
\hline genus & Candelabrum \\
\hline genus & Catharacta \\
\hline species & Chaenocephalus aceratus \\
\hline species & Charcotia obesa \\
\hline species & Chionis albus \\
\hline class & Polyplacophora \\
\hline phylum & Chlorophyta \\
\hline phylum & Cnidaria \\
\hline class & Collembola \\
\hline subphylum & Crustacea \\
\hline species & Cuenotaster involutus \\
\hline order & Cumacea \\
\hline species & Daption capense \\
\hline order & Decapoda \\
\hline genus & Dendrilla \\
\hline genus & Desmarestia \\
\hline species & Desmarestia antarctica \\
\hline species & Diomedea exulans \\
\hline species & Diplasterias brucei \\
\hline genus & Doris \\
\hline phylum & Echinodermata \\
\hline class & Eucarida \\
\hline genus & Euneognathia \\
\hline
\end{tabular}




\begin{tabular}{|c|c|}
\hline order & Euphausiacea \\
\hline genus & Eusirus \\
\hline genus & Flabelligera \\
\hline species & Fregetta tropica \\
\hline species & Fulmarus glacialoides \\
\hline class & Gastropoda \\
\hline species & Glyphoperidium bursa \\
\hline genus & Glyptonotus \\
\hline species & Glyptonotus antarcticus \\
\hline species & Gobionotothen gibberifrons \\
\hline genus & Granaster \\
\hline species & Granaster nutrix \\
\hline species & Halobaena caerulea \\
\hline genus & Harpagifer \\
\hline species & Harpagifer antarcticus \\
\hline genus & Himantothallus \\
\hline class & Holothuroidea \\
\hline species & Homaxinella balfourensis \\
\hline species & Hydrurga leptonyx \\
\hline order & Isopoda \\
\hline genus & Labidiaster \\
\hline species & Lagenorhynchus australis \\
\hline species & Lagenorhynchus cruciger \\
\hline species & Larus dominicanus \\
\hline species & Laternula elliptica \\
\hline species & Leptonychotes weddellii \\
\hline species & Lindbergichthys nudifrons \\
\hline species & Lobodon carcinophagus \\
\hline genus & Lysasterias \\
\hline order & Lysianassoidea \\
\hline species & Macronectes giganteus \\
\hline
\end{tabular}




\begin{tabular}{|c|c|}
\hline genus & Margarella \\
\hline species & Margarella antarctic \\
\hline species & Megaptera novaeangliae \\
\hline phylum & Mollusca \\
\hline genus & Mycale \\
\hline species & Mycale (Oxymycale) acerata \\
\hline order & Mysida \\
\hline species & Nacella concinna \\
\hline phylum & Nematoda \\
\hline phylum & Nemertea \\
\hline species & Neosmilaster georgianus \\
\hline species & Notothenia coriiceps \\
\hline species & Notothenia rossii \\
\hline order & Nudibranchia \\
\hline species & Oceanites oceanicus \\
\hline genus & Odontaster \\
\hline species & Odontaster meridionalis \\
\hline species & Odontaster pearsei \\
\hline species & Odontaster roseus \\
\hline species & Odontaster validus \\
\hline genus & Ophionotus \\
\hline species & Ophionotus victoriae \\
\hline class & Ophiuroidea \\
\hline class & Ostracoda \\
\hline species & Otaria byronia \\
\hline genus & Pachyptila \\
\hline species & Pachyptila desolata \\
\hline species & Pagodroma nivea \\
\hline genus & Parborlasia \\
\hline species & Parborlasia corrugatus \\
\hline species & Pelecanoides urinatrix \\
\hline
\end{tabular}




\begin{tabular}{|c|c|}
\hline genus & Perknaster \\
\hline species & Phalacrocorax atriceps \\
\hline species & Phoebetria palpebrata \\
\hline order & Pinnipedia \\
\hline class & Polychaeta \\
\hline class & Polyplacophora \\
\hline phylum & Porifera \\
\hline species & Procellaria aequinoctialis \\
\hline species & Procellaria cinerea \\
\hline species & Pseudorchomene plebs \\
\hline species & Psilaster charcoti \\
\hline species & Pterodroma mollis \\
\hline species & Puffinus griseus \\
\hline class & Pycnogonida \\
\hline genus & Pygoscelis \\
\hline species & Pygoscelis adeliae \\
\hline species & Pygoscelis antarcticus \\
\hline species & Pygoscelis papua \\
\hline order & Sphenisciformes \\
\hline species & Spheniscus magellanicus \\
\hline genus & Sphyraena \\
\hline species & Staurocucumis turqueti \\
\hline species & Stercorarius chilensis \\
\hline species & Stercorarius maccormicki \\
\hline species & Sterechinus neumayeri \\
\hline species & Sterna hirundinacea \\
\hline order & Tanaidacea \\
\hline species & Thalassarche chrysostoma \\
\hline species & Thalassarche melanophris \\
\hline species & Thalassoica antarctica \\
\hline species & Trematocarpus antarcticus \\
\hline
\end{tabular}




\begin{tabular}{|l|l|}
\hline species & Trematomus bernacchii \\
\hline species & Trematomus newnesi \\
\hline subphylum & Tunicata \\
\hline class & Echinoidea \\
\hline species & Sterechinus neumayeri \\
\hline
\end{tabular}

\section{Temporal coverage}

Data range: 2019-2-23 - 2019-3-24.

\section{Collection data}

Collection name: B121 expedition collection, hosted at the BIOMAR Lab, Université Libre de Bruxelles

Specimen preservation method: ethanol, deep frozen, RNA later, other

\section{Usage licence}

Usage licence: Creative Commons Public Domain Waiver (CC-Zero)

IP rights notes: This work is licensed under a Creative Commons Attribution (CC-BY) 4.0 Licence.

\section{Data resources}

Data package title: The Belgica 121 expedition to the Western Antarctic Peninsula: a high resolution biodiversity census

Resource link: https://www.gbif.org/dataset/b635be2e-76ea-4600-8f83-549601653c0a

\section{Number of data sets: 1}

Data set name: The Belgica 121 expedition to the Western Antarctic Peninsula: a high resolution biodiversity census

Character set: UTF-8

Data format: Darwin Core

Description: This dataset (Danis 2021) pertains to the outputs of the Belgica 121 (B121) expedition, whose aim was to explore the surroundings of the Gerlache Strait (Western Antarctic Peninsula) and to carry out a detailed biodiversity census focusing 
on intertidal and shallow areas using both classic descriptive marine ecology methods as well as state-of-the-art techniques (habitat mapping, genetics, trophic ecology). This dataset will offer access to the raw data on biodiversity occurrences, obtained using a range of methods.

\begin{tabular}{|c|c|}
\hline Column label & Column description \\
\hline datasetID & $\begin{array}{l}\text { An identifier for the set of data. May be a global unique identifier or an identifier specific } \\
\text { to a collection or institution. }\end{array}$ \\
\hline occurrencelD & $\begin{array}{l}\text { An identifier for the Occurrence (as opposed to a particular digital record of the } \\
\text { occurrence). In the absence of a persistent global unique identifier, construct one from a } \\
\text { combination of identifiers in the record that will most closely make the occurrencelD } \\
\text { globally unique. }\end{array}$ \\
\hline eventID & $\begin{array}{l}\text { An identifier for the set of information associated with an Event (something that occurs at } \\
\text { a place and time). May be a global unique identifier or an identifier specific to the dataset. }\end{array}$ \\
\hline recordNumber & $\begin{array}{l}\text { An identifier given to the Occurrence at the time it was recorded. Often serves as a link } \\
\text { between field notes and an Occurrence record, such as a specimen collector's number. }\end{array}$ \\
\hline eventDate & $\begin{array}{l}\text { The date-time or interval during which an Event occurred. For occurrences, this is the } \\
\text { date-time when the event was recorded. Not suitable for a time in a geological context. }\end{array}$ \\
\hline year & The four-digit year in which the Event occurred, according to the Common Era Calendar. \\
\hline month & The integer month in which the Event occurred. \\
\hline day & The integer day of the month on which the Event occurred. \\
\hline eventTime & The time or interval during which an Event occurred. \\
\hline vernacularName & A common or vernacular name. \\
\hline scientificName & $\begin{array}{l}\text { The full scientific name, with authorship and date information, if known. When forming } \\
\text { part of an Identification, this should be the name in the lowest level taxonomic rank that } \\
\text { can be determined. This term should not contain identification qualifications, which } \\
\text { should instead be supplied in the IdentificationQualifier term. }\end{array}$ \\
\hline occurrenceStatus & A statement about the presence or absence of a Taxon at a Location. \\
\hline institutionID & $\begin{array}{l}\text { An identifier for the institution having custody of the object(s) or information referred to in } \\
\text { the record. }\end{array}$ \\
\hline basisOfRecord & The specific nature of the data record. \\
\hline individualCount & The number of individuals represented present at the time of the Occurrence. \\
\hline footprintWKT & $\begin{array}{l}\text { A Well-Known Text (WKT) representation of the shape (footprint, geometry) that defines } \\
\text { the Location. A Location may have both a point-radius representation (see } \\
\text { decimalLatitude) and a footprint representation and they may differ from each other. }\end{array}$ \\
\hline
\end{tabular}




\begin{tabular}{|c|c|}
\hline decimalLatitude & $\begin{array}{l}\text { The geographic latitude (in decimal degrees, using the spatial reference system given in } \\
\text { geodeticDatum) of the geographic centre of a Location. Positive values are north of the } \\
\text { Equator, negative values are south of it. Legal values lie between }-90 \text { and } 90 \text {, inclusive. }\end{array}$ \\
\hline decimalLongitude & $\begin{array}{l}\text { The geographic longitude (in decimal degrees, using the spatial reference system given } \\
\text { in geodeticDatum) of the geographic centre of a Location. Positive values are east of the } \\
\text { Greenwich Meridian, negative values are west of it. Legal values lie between }-180 \text { and } \\
180 \text {, inclusive. }\end{array}$ \\
\hline coordinatePrecision & $\begin{array}{l}\text { The horizontal distance (in metres) from the given decimalLatitude and decimalLongitude } \\
\text { describing the smallest circle containing the whole of the Location. Leave the value } \\
\text { empty if the uncertainty is unknown, cannot be estimated or is not applicable (because } \\
\text { there are no coordinates). Zero is not a valid value for this term. }\end{array}$ \\
\hline occurrenceRemarks & Comments or notes about the Occurrence. \\
\hline genus & The full scientific name of the genus in which the taxon is classified. \\
\hline specificEpithet & The name of the first or species epithet of the scientificName. \\
\hline identifiedBy & $\begin{array}{l}\text { A list (concatenated and separated) of names of people, groups or organisations who } \\
\text { assigned the Taxon to the subject. }\end{array}$ \\
\hline recordedBy & $\begin{array}{l}\text { A list (concatenated and separated) of names of people, groups or organisations } \\
\text { responsible for recording the original Occurrence. The primary collector or observer, } \\
\text { especially one who applies a personal identifier (recordNumber), should be listed first. }\end{array}$ \\
\hline preparations & $\begin{array}{l}\text { A list (concatenated and separated) of preparations and preservation methods for a } \\
\text { specimen. }\end{array}$ \\
\hline dynamicProperties & $\begin{array}{l}\text { A list of additional measurements, facts, characteristics or assertions about the record. } \\
\text { Meant to provide a mechanism for structured content. }\end{array}$ \\
\hline eventRemarks & Comments or notes about the Event. \\
\hline locality & $\begin{array}{l}\text { The specific description of the place. Less specific geographic information can be } \\
\text { provided in other geographic terms (higherGeography, continent, country, stateProvince, } \\
\text { county, municipality, waterBody, island, islandGroup). This term may contain information } \\
\text { modified from the original to correct perceived errors or standardise the description. }\end{array}$ \\
\hline maximumDepthInMetres & The greater depth of a range of depth below the local surface, in metres. \\
\hline minimumDepthInMetres & The lesser depth of a range of depth below the local surface, in metres. \\
\hline modified & The most recent date-time on which the resource was changed. \\
\hline parentEventID & An identifier for the broader Event that groups this and potentially other Events. \\
\hline samplingProtocol & The name of, reference to, or description of the method or protocol used during an Event. \\
\hline type & The nature or genre of the resource. \\
\hline waterbody & The name of the water body in which the Location occurs. \\
\hline class & The full scientific name of the class in which the taxon is classified. \\
\hline
\end{tabular}




\begin{tabular}{|l|l|}
\hline family & The full scientific name of the family in which the taxon is classified. \\
\hline fieldNumber & $\begin{array}{l}\text { An identifier given to the event in the field. Often serves as a link between field notes and } \\
\text { the Event. }\end{array}$ \\
\hline identificationQualifier & $\begin{array}{l}\text { A brief phrase or a standard term ("cf.", "aff.") to express the determiner's doubts about } \\
\text { the Identification. }\end{array}$ \\
\hline kingdom & The full scientific name of the kingdom in which the taxon is classified. \\
\hline phylum & The full scientific name of the phylum or division in which the taxon is classified. \\
\hline order & The full scientific name of the order in which the taxon is classified. \\
\hline scientificNamelD & An identifier for the nomenclatural (not taxonomic) details of a scientific name. \\
\hline
\end{tabular}

\section{Acknowledgements}

The B121 expedition was funded through various channels. The B121 team has also benefited from a lot of support, time and expertise from the international networks it has been collaborating with for a long time.

\section{Funding of the expedition:}

The Belgian Science Policy Office (BELSPO): the bulk of the funding of the expedition was channelled through two research projects funded by BELSPO, RECTO (promoter: Isa Schön, Royal Belgian Institute of Natural Sciences) and vERSO (promoter: Bruno Danis, Université Libre de Bruxelles).

The Cabinet Marcourt (Federation Wallonia-Brussels - Research, Education) supported the expedition for functioning and various equipment.

The Belgian Federal Public Service Health, Food Chain Safety and Environment funded the ship time necessary to the visit of historic monument $\mathrm{N}^{\circ} 45$ dedicated to the Belgica expedition led by Adrien de Gerlache.

The Fund for Scientific Research (FNRS), and the Research Foundation Flanders (FWO) have funded travel expenses for some B121 team members.

The B121 team also acknowledge financial support from the Fonds Léopold III and the Royal Belgian Zoological Society.

\section{Personal thanks:}

The B121 Team would like to thank the following persons who have been pivotal in the success of the expedition, from logistic, funding or scientific points of view:

Maaike Van Cauwenberghe (Belgian Science Policy Office, Belgium)

Anton Van de Putte (Royal Belgian Institute of Natural Sciences, Belgium) 
François André (SPF Environment, Belgium)

José Retamales (Instituto Antártico Chileno: INACH, Chile)

Karin Gerard (Universidad de Magallanes (UMAG), Chile)

Alain Noro (Royal Belgian Institute of Natural Sciences, Belgium)

Nina Machner (Alfred Wegener Institute, Germany)

Irene Schloss (Centro Austral de Investigaciones Científicas del Consejo Nacional de Investigaciones Científicas y Técnicas, Argentina)

\section{Author contributions}

$\mathrm{BD}, \mathrm{HC}, \mathrm{FP}, \mathrm{CG}, \mathrm{QJ}, \mathrm{CM}, \mathrm{BW}, \mathrm{FMH}, \mathrm{HR}$ and TS contributed equally to the drafting and data preparation for this manuscript.

\section{References}

- $\quad$ Carlini A, Coria NR, Santos MM, Negrete J, Juares MA, Daneri GA (2009) Responses of Pygoscelis adeliae and $P$. papua populations to environmental changes at Isla 25 de Mayo (King George Island). Polar Biology 32 (10): 1427-1433. https://doi.org/10.1007/ s00300-009-0637-y

- $\quad$ Chown S, Clarke A, Fraser C, Cary SC, Moon K, McGeoch M (2015) The changing form of Antarctic biodiversity. Nature 522 (7557): 431-438. https://doi.org/10.1038/ nature14505

- $\quad$ Clarke A, Murphy EJ, Meredith MP, King JC, Peck LS, Barnes DA, Smith RC (2007) Climate change and the marine ecosystem of the western Antarctic Peninsula. Philosophical Transactions of the Royal Society B: Biological Sciences 362 (1477): 149-166. https://doi.org/10.1098/rstb.2006.1958

- Constable A, Melbourne-Thomas J, Corney S, Arrigo K, Barbraud C, Barnes DA, Bindoff N, Boyd P, Brandt A, Costa D, Davidson A, Ducklow H, Emmerson L, Fukuchi M, Gutt J, Hindell M, Hofmann E, Hosie G, lida T, Jacob S, Johnston N, Kawaguchi S, Kokubun N, Koubbi P, Lea M, Makhado A, Massom R, Meiners K, Meredith M, Murphy E, Nicol S, Reid K, Richerson K, Riddle M, Rintoul S, Smith W, Southwell C, Stark J, Sumner M, Swadling K, Takahashi K, Trathan P, Welsford D, Weimerskirch H, Westwood K, Wienecke B, Wolf-Gladrow D, Wright S, Xavier J, Ziegler P (2014) Climate change and Southern Ocean ecosystems I: how changes in physical habitats directly affect marine biota. Global Change Biology 20 (10): 3004-3025. https://doi.org/ 10.1111/gcb.12623

- $\quad$ Convey P, Chown S, Clarke A, Barnes DA, Bokhorst S, Cummings V, Ducklow H, Frati F, Green TGA, Gordon S, Griffiths H, Howard-Williams C, Huiskes AL, Laybourn-Parry J, Lyons WB, McMinn A, Morley S, Peck L, Quesada A, Robinson S, Schiaparelli S, Wall D (2014) The spatial structure of Antarctic biodiversity. Ecological Monographs 84 (2): 203-244. https://doi.org/10.1890/12-2216.1 
- Danis B, Christiansen H, Guillaumot C, Heindler F, Jossart Q, Lucas K, Moreau C, Pasotti F, Robert H, Wallis B, Saucède T (2019) Report of the Belgica 121 expedition to the West Antarctic Peninsula. URL: http://belgica120.be/wp-content/uploads/2019/05/

B121-Cruise-report.pdf

- Danis B, et al. (2021) The Belgica 121 expedition to the Western Antarctic Peninsula: a high resolution biodiversity census. Sampling event dataset. Version 1.6. SCAR AntOBIS. URL: https://doi.org/10.15468/56bv6z

- De Broyer C, Koubbi P, Griffiths HJ, Raymond B, D'udekem d'Acoz C, Van de Putte AP, Danis B, David B, Grant S, Gutt J, Held C, Hosie G, Huettmann F, Post A, RopertCoudert Y (Eds) (2014) Biogeographic atlas of the Southern Ocean. Scientific Committee on Antarctic Research, Cambridge, 498 pp. [ISBN 978-0-948277-28-3] https://doi.org/10.1017/S0032247415000984

- Ducklow H, Fraser W, Meredith M, Stammerjohn S, Doney S, Martinson D, Sailley S, Schofield O, Steinberg D, Venables H, Amsler C (2013) West Antarctic Peninsula: An ice-dependent coastal marine ecosystem in transition. Oceanography 26 (3): 190-203. https://doi.org/10.5670/oceanog.2013.62

- Friedlander A, Goodell W, Salinas-de-León P, Ballesteros E, Berkenpas E, Capurro A, Cárdenas $C$, Hüne M, Lagger C, Landaeta M, Muñoz A, Santos M, Turchik A, Werner R, Sala $E$ (2020) Spatial patterns of continental shelf faunal community structure along the Western Antarctic Peninsula. PLOS One 15 (10). https://doi.org/10.1371/journal.pone. $\underline{0239895}$

- Grange L, Smith C (2013) Megafaunal communities in rapidly warming fjords along the West Antarctic Peninsula: Hotspots of abundance and beta diversity. PLOS One 8 (12). https://doi.org/10.1371/journal.pone.0077917

- Griffiths H (2010) Antarctic marine biodiversity - what do we know about the distribution of life in the Southern Ocean? PLOS One 5 (8). https://doi.org/10.1371/journal.pone. 0011683

- $\quad$ Griffiths H, Danis B, Clarke A (2011) Quantifying Antarctic marine biodiversity: The SCAR-MarBIN data portal. Deep Sea Research Part II: Topical Studies in Oceanography 58 (1-2): 18-29. https://doi.org/10.1016/j.dsr2.2010.10.008

- Gutt J, Bertler N, Bracegirdle T, Buschmann A, Comiso J, Hosie G, Isla E, Schloss I, Smith C, Tournadre J, Xavier J (2015) The Southern Ocean ecosystem under multiple climate change stresses - an integrated circumpolar assessment. Global Change Biology 21 (4): 1434-1453. https://doi.org/10.1111/gcb.12794

- Kennicutt MC, Chown SL, Cassano JJ, Liggett D, Peck LS, Massom R, Rintoul SR, Storey J, Vaughan DG, Wilson TJ, Allison I, Ayton J, Badhe R, Baeseman J, Barrett PJ, Bell RE, Bertler N, Bo S, Brandt A, Bromwich D, Cary SC, Clark MS, Convey P, Costa ES, Cowan D, Deconto R, Dunbar R, Elfring C, Escutia C, Francis J, Fricker HA, Fukuchi M, Gilbert N, Gutt J, Havermans C, Hik D, Hosie G, Jones C, Kim YD, Le Maho Y, Lee SH, Leppe M, Leitchenkov G, Li X, Lipenkov V, Lochte K, López-Martínez J, Lüdecke C, Lyons W, Marenssi S, Miller H, Morozova P, Naish T, Nayak S, Ravindra R, Retamales J, Ricci CA, Rogan-Finnemore M, Ropert-Coudert $Y$, Samah AA, Sanson L, Scambos T, Schloss IR, Shiraishi K, Siegert MJ, Simões JC, Storey B, Sparrow MD, Wall DH, Walsh JC, Wilson G, Winther JG, Xavier JC, Yang H, Sutherland WJ (2015) A roadmap for Antarctic and Southern Ocean science for the next two decades and beyond. Antarctic Science 27 (1): 3-18. https://doi.org/10.1017/S0954102014000674 
- $\quad$ Oliver TH, Heard MS, Isaac NJ, Roy DB, Procter D, Eigenbrod F, Proena V (2015) Biodiversity and resilience of ecosystem functions. Trends in Ecology \& Evolution 30 (11): 673-684. https://doi.org/10.1016/j.tree.2015.08.009

- $\quad$ Pasotti F, Saravia LA, De Troch M, Tarantelli MS, Sahade R, Vanreusel A (2015) Benthic trophic interactions in an Antarctic shallow water ecosystem affected by recent glacier retreat. PLOS One 10 (11): e0141742. https://doi.org/10.1371/journal.pone. 0141742

- Sahade R, Lagger C, Torre L, Momo F, Monien P, Schloss I, Barnes DA, Servetto N, Tarantelli S, Tatián M, Zamboni N, Abele D (2015) Climate change and glacier retreat drive shifts in an Antarctic benthic ecosystem. Science Advances 1 (10). https://doi.org/ 10.1126/sciadv. 1500050

- $\quad$ Siegert M, Atkinson A, Banwell A, Brandon M, Convey P, Davies B, Downie R, Edwards T, Hubbard B, Marshall G, Rogelj J, Rumble J, Stroeve J, Vaughan D (2019) The Antarctic Peninsula under a $1.5^{\circ} \mathrm{C}$ global warming scenario. Frontiers in Environmental Science 7 https://doi.org/10.3389/fenvs.2019.00102

- Stammerjohn SE, Martinson DG, Smith RC, Yuan X, Rind D (2008) Trends in Antarctic annual sea ice retreat and advance and their relation to El Niño-Southern Oscillation and Southern Annular Mode variability. Journal of Geophysical Research 113 (C3). https://doi.org/10.1029/2007JC004269

- Turner J, Barrand N, Bracegirdle T, Convey P, Jarvis M, Jenkins A, Marshall G, Meredith M, Roscoe H, Shanklin J, French J, Goosse H, Guglielmin M, Gutt J, Jacobs S, Kennicutt M, Masson-Delmotte V, Mayewski P, Navarro F, Robinson S, Scambos T, Sparrow M, Summerhayes C, Speer K, Klepikov A (2014) Antarctic climate change and the environment: an update. Polar Record 50 (3): 237-259. https://doi.org/10.1017/ S0032247413000296 